\title{
Sensitive and robust gene expression changes in fish exposed to estrogen - a microarray approach Lina Gunnarsson ${ }^{1}$, Erik Kristiansson ${ }^{2}$, Lars Förlin ${ }^{3}$, Olle Nerman ${ }^{2}$ and D G Joakim Larsson*1
}

Address: ${ }^{1}$ Department of Neuroscience and Physiology, the Sahlgrenska Academy at Göteborg University, SE-405 30 Göteborg, Sweden, 2Department of Mathematical Statistics, Chalmers University of Technology, SE-412 96 Göteborg, Sweden and 32Department of Zoology/ Zoophysiology, Göteborg University, SE-405 30 Göteborg, Sweden

Email: Lina Gunnarsson - lina.gunnarsson@fysiologi.gu.se; Erik Kristiansson - erikkr@math.chalmers.se; Lars Förlin - lars.forlin@zool.gu.se; Olle Nerman - nerman@chalmers.se; D G Joakim Larsson* - joakim.larsson@fysiologi.gu.se

* Corresponding author

Published: 7 June 2007

BMC Genomics 2007, 8:149 doi:10.1/86/147|-2164-8-149
Received: 22 December 2006

Accepted: 7 June 2007

This article is available from: http://www.biomedcentral.com/I47I-2/64/8/149

(C) 2007 Gunnarsson et al; licensee BioMed Central Ltd.

This is an Open Access article distributed under the terms of the Creative Commons Attribution License (http://creativecommons.org/licenses/by/2.0), which permits unrestricted use, distribution, and reproduction in any medium, provided the original work is properly cited.

\begin{abstract}
Background: Vitellogenin is a well established biomarker for estrogenic exposure in fish. However, effects on gonadal differentiation at concentrations of estrogen not sufficient to give rise to a measurable vitellogenin response suggest that more sensitive biomarkers would be useful. Induction of zona pellucida genes may be more sensitive but their specificities are not as clear. The objective of this study was to find additional sensitive and robust candidate biomarkers of estrogenic exposure.
\end{abstract}

Results: Hepatic mRNA expression profiles were characterized in juvenile rainbow trout exposed to a measured concentration of 0.87 and $10 \mathrm{ng}$ ethinylestradiol/L using a salmonid CDNA microarray. The higher concentration was used to guide the subsequent identification of generally more subtle responses at the low concentration not sufficient to induce vitellogenin. A metaanalysis was performed with data from the present study and three similar microarray studies using different fish species and platforms. Within the generated list of presumably robust responses, several well-known estrogen-regulated genes were identified. Two genes, confirmed by quantitative RT-PCR (qPCR), fulfilled both the criteria of high sensitivity and robustness; the induction of the genes encoding zona pellucida protein 3 and a nucleoside diphosphate kinase (nm23).

Conclusion: The cross-species, cross-platform meta-analysis correctly identified several robust responses. This adds confidence to our approach used for identifying candidate biomarkers. Specifically, we propose that analyses of an $\mathrm{nm} 23$ gene together with zona pellucida genes may increase the possibilities to detect an exposure to low levels of estrogenic compounds in fish.

\section{Background}

The contraceptive estrogen, ethinylestradiol $\left(\mathrm{EE}_{2}\right)$ is an important contributor to the feminization of fish downstream from sewage treatment works [1-5]. This discovery was greatly facilitated by the use of vitellogenin (VTG) as a biomarker. VTG is produced in the liver of sexually maturing female fish under the influence of endogenous estrogen. Normally, VTG is not expressed in males or juve- 
niles, unless they are exposed to estrogens via water or food. Both VTG mRNA and protein in male and juvenile fish have thus become established biomarkers for exposure to environmental estrogens [6]. However, estrogens can effect gonadal sex differentiation of fish at concentration not sufficient to give rise to a measurable VTG response [7]. It has also been shown that life cycle exposure of fathead minnow to an inordinately low concentration of $\mathrm{EE}_{2}(0.32 \mathrm{ng} / \mathrm{L})$ was sufficient to decrease the egg fertilisation and to skew the sex ratios towards female[8]. This suggests that more sensitive biomarkers would be useful. Zona pellucida (ZP) genes may be more sensitive than VTG [9] but their specificity for estrogens is not as clear [10-12]. Additional, sensitive biomarkers would thus increase our possibilities to identify exposure to low, but biologically important concentrations of estrogens.

Rapidly accumulating data on genomes and proteomes have increased the possibilities to use different types of discovery-driven methods in ecotoxicology $[13,14]$. The large number of potential responses that can be studied with microarrays renders the method suitable for identifying candidate biomarkers of exposure [15-20]. Such candidates may then be further evaluated to find if they are useful as biomarkers. In general, a good biomarker should be sensitive, specific and robust. A robust response implies for example that it should be measurable at complex exposure situations, at different exposure concentrations, at different temperatures, after different exposure times, by different analytical approaches, in different labs and preferably also in different species.

The main objective of the present study was to use microarrays to find novel, sensitive and robust biomarkers of estrogenic exposure in fish. We have used a salmonid cDNA microarray from cGRASP [21] to analyze hepatic expression profiles in juvenile rainbow trout (Oncorhynchus mykiss) exposed to $\mathrm{EE}_{2}$ in vivo. The responses identified at a high concentration of $\mathrm{EE}_{2}$ were used to guide the subsequent identification of generally more subtle responses at a low concentration of estrogen. We also identified estrogen-responses shared between fish species, experimental conditions and analytical platforms. This was achieved by a meta-analysis using our dataset together with results from three recently published articles describing hepatic gene expression profiles in fish exposed to estrogens $[16,20,22]$.

\section{Results}

\section{Sensitive gene-expression changes}

Both male and female juvenile fish exposed to $0.87 \mathrm{ng}$ $\mathrm{EE}_{2} / \mathrm{L}$ were analyzed with microarray. The microarray analysis of female fish suggested that only three out of four females had an induced expression of the known estrogen-responsive gene ZP3. In contrast, an induction was present in all eight males. This observation suggested that some juvenile females may have sufficient endogenous estrogen to induce sensitive estrogen-responsive genes. Thus, in our search for genes responding to low concentrations of estrogens only the microarray results from male fish were used.

Thirty-six sets of cDNAs (presumably corresponding to 29 genes) were regulated in male fish both by the low and the high concentration of $\mathrm{EE}_{2}$ (Table 1). All of the cDNAs responded in a dose-dependent manner. ZP3 was the most differentially expressed gene in fish exposed to both high and low concentrations with a fold change of 84 and 3.5 respectively. VTG was not affected by the low concen-

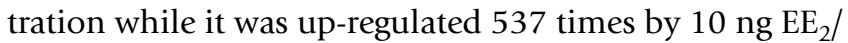
$\mathrm{L}$ as measured by quantitative RT-PCR (qPCR) (Figure 1).

\section{Robust gene-expression changes}

A meta-analysis was performed with the aim to identify robust estrogen-responsive genes. The microarray data from fish (both sexes) exposed to $10 \mathrm{ng} / \mathrm{L}$ from the present study and available microarray data from three other exposure studies with fish and estradiol $\left(\mathrm{E}_{2}\right)$ or $\mathrm{EE}_{2}$ were used in the meta-analysis $[16,20,22]$. Information about the different studies is shown in Table 2. Transcripts (360) presumably corresponding to 55 genes or groups of paralog genes were identified as differentially expressed in at least two of the four different studies (see Additional file 1). VTG and ZP3 were differentially expressed in all four studies and nine genes had an altered expression in at least three studies (Figure 2). It should be noted that ZP1 and the estrogen receptor- $\alpha$, which are well-know estrogen-responsive genes in fish, have poor sequence representation on the cGRASP microarrays and are therefore not present in Figure 2.

\section{Confirmation of microarray data with quantitative RT- PCR}

Genes that were likely to be both sensitive (Table 1) and robust (Figure 2) were chosen for subsequent qPCR analysis. Three genes fulfilled these criteria: ZP3, a nucleoside diphosphate kinase (nm23) and fatty acid binding protein 3 (fabp3 or H-FABP). In addition, VTG was subjected to the qPCR analysis as well as the reference gene ubiquitin. In accordance with the microarray results the expression of VTG, ZP3 and nm 23 were significantly induced in fish exposed to the high concentration. Also, as suggested by the microarrays, ZP3 and nm23 were significantly induced by the low concentration as well, whereas VTG expression was not induced (Figure 1). In stark contrast to the microarray results fabp3 had no tendency to any regulation caused by the treatment but showed a large variation within each treatment group (data not shown). The fabp 3 and $n m 23$ qPCR products were sequenced in order to confirm the amplification of the right products and 
Table I: Estrogen-sensitive genes.

\begin{tabular}{|c|c|c|c|}
\hline cGRASP ID & M-value $0.87 \mathrm{ng} / \mathrm{L}$ & M-value $10 \mathrm{ng} / \mathrm{L}$ & Annotation \\
\hline CK991I165 & 1.40 & 5.60 & $\begin{array}{l}{[\mathrm{GO}][\mathrm{PI} 076 \mathrm{I}] \text { Zona pellucida sperm-binding protein } 3 \text { precursor (Zona }} \\
\text { pellucida glycoprotein ZP3) (Sperm receptor) (Zona pellucida protein C), }\end{array}$ \\
\hline CB492227 & -0.23 & -0.34 & $\begin{array}{l}\text { [GO] [P23506] Protein-L-isoaspartate(D-aspartate) O-methyltransferase (EC 2,I,I,77) } \\
\text { (Protein-beta-aspartate methyltransferase) (PIMT) (Protein L- isoaspartyl/D-aspartyl } \\
\text { methyltransferase) }\end{array}$ \\
\hline CA054422 & 0.22 & 0.43 & UNKNOWN \\
\hline CB496664 & 0.30 & 0.50 & [GO] [Q9D0EI] Heterogeneous nuclear ribonucleoprotein M (hnRNP M), \\
\hline CB497378 & 0.27 & 0.69 & $\begin{array}{l}\text { [GO] [PI5532] Nucleoside diphosphate kinase A (EC 2,7,4,6) (NDK A) } \\
\text { (NDP kinase A) (Tumor metastatic process-associated protein) (Metastasis } \\
\text { inhibition factor NM23) (NDPK-A) (nm23-MI), }\end{array}$ \\
\hline CB5II 030 & 0.27 & 0.47 & $\begin{array}{l}\text { [GO] [PI5532] Nucleoside diphosphate kinase A (EC 2,7,4,6) (NDK A) } \\
\text { (NDP kinase A) (Tumor metastatic process-associated protein) (Metastasis } \\
\text { inhibition factor NM23) (NDPK-A) (nm23-MI) }\end{array}$ \\
\hline CK991305 & 0.27 & 0.59 & $\begin{array}{l}\text { [GO] [Q0 I 768] Nucleoside diphosphate kinase B (EC 2,7,4,6) (NDK B) } \\
\text { (NDP kinase B) (nm23-M2) (PI8), }\end{array}$ \\
\hline CA0379I5 & 0.30 & 0.38 & $\begin{array}{l}\text { [GO] [P35505] Fumarylacetoacetase (EC 3,7,1,2) (Fumarylacetoacetate hydrolase) } \\
\text { (Beta-diketonase) (FAA), }\end{array}$ \\
\hline CA060608 & 0.21 & 0.46 & $\begin{array}{l}\text { [GO] [P56384] ATP synthase lipid-binding protein, mitochondrial precursor (EC } \\
\text { 3,6,3,14) (ATP synthase proteolipid P3) (ATPase protein 9) (ATPase subunit C), }\end{array}$ \\
\hline CB496562 & 0.16 & 0.32 & $\begin{array}{l}\text { [GO] [Q9CY58] Plasminogen activator inhibitor I RNA-binding protein (PAII RNA- } \\
\text { binding protein I) (PAI-RBPI), }\end{array}$ \\
\hline CB516182 & 0.46 & 0.56 & $\begin{array}{l}\text { [GO] [O08709] Peroxiredoxin } 6 \text { (EC I,II,I,I5) (Antioxidant protein 2) (I-Cys } \\
\text { peroxiredoxin) (I-Cys PRX) (Acidic calcium-independent phospholipase A2) (EC 3, I, I,- } \\
\text { (aiPLA2) (Non-selenium glutathione peroxidase) (EC I,II,I,7) (NSGPx), }\end{array}$ \\
\hline CB5II422 & 0.25 & 0.50 & $\begin{array}{l}\text { [GO] [PI 5532] Nucleoside diphosphate kinase A (EC 2,7,4,6) (NDK A) } \\
\text { (NDP kinase A) (Tumor metastatic process-associated protein) (Metastasis } \\
\text { inhibition factor NM23) (NDPK-A) (nm23-MI), }\end{array}$ \\
\hline CB49693I & 0.80 & 2.58 & $\begin{array}{l}\text { [GO] [P I I 404] Fatty acid-binding protein, heart (H-FABP) (Heart-type fatty } \\
\text { acid- binding protein) (Mammary-derived growth inhibitor) (MDGI), }\end{array}$ \\
\hline CB497374 & 0.60 & 2.08 & $\begin{array}{l}\text { [GO] [P I I 404] Fatty acid-binding protein, heart (H-FABP) (Heart-type fatty } \\
\text { acid- binding protein) (Mammary-derived growth inhibitor) (MDGI), }\end{array}$ \\
\hline CB505692 & -0.33 & -0.42 & UNKNOWN \\
\hline CB497I74 & 0.53 & 1.71 & $\begin{array}{l}\text { [NR] [XP_423045] PREDICTED: similar to nudix (nucleoside diphosphate linked moiety } \\
\text { X)-type motif 7; coenzyme A diphosphatase [Gallus gallus] }\end{array}$ \\
\hline CB497649 & 0.21 & 0.52 & $\begin{array}{l}\text { [GO] [Q0 I 768] Nucleoside diphosphate kinase B (EC 2,7,4,6) (NDK B) } \\
\text { (NDP kinase B) (nm23-M2) (PI8), }\end{array}$ \\
\hline CA037988 & 0.23 & 0.41 & $\begin{array}{l}\text { [NT] [AJ488I55] Pachymedusa dacnicolor partial mRNA for ribosomal protein SI6 } \\
\text { (rps } 16 \text { gene) }\end{array}$ \\
\hline CB499596 & 0.14 & 0.49 & [NR] [NP_0772I7] hydroxysteroid dehydrogenase like 2 [Mus musculus] \\
\hline CB489314 & -1.01 & -1.11 & UNKNOWN \\
\hline CA769854 & 0.64 & 2.17 & $\begin{array}{l}\text { [GO] [P I I 404] Fatty acid-binding protein, heart (H-FABP) (Heart-type fatty } \\
\text { acid- binding protein) (Mammary-derived growth inhibitor) (MDGI), }\end{array}$ \\
\hline CB509453 & -0.32 & -0.48 & [GO] [O16797] 60S ribosomal protein L3, \\
\hline CB50082I & -0.26 & -0.36 & [GO] [P62918] 60S ribosomal protein L8, \\
\hline CB492885 & -0.15 & -0.31 & UNKNOWN \\
\hline CA061403 & 0.42 & 0.72 & UNKNOWN \\
\hline CB498219 & 0.24 & 0.51 & $\begin{array}{l}\text { [NR] [XP_6I32/8] PREDICTED: similar to 24-dehydrocholesterol reductase } \\
\text { precursor, partial [Bos taurus] }\end{array}$ \\
\hline CA054I68 & -0.39 & -0.58 & UNKNOWN \\
\hline CB5I5449 & 0.34 & -0.60 & $\begin{array}{l}\text { [GO] [P50247] Adenosylhomocysteinase (EC 3,3,I,I) (S-adenosyl-L-homocysteine } \\
\text { hydrolase) (AdoHcyase) (Liver copper binding protein) (CUBP), }\end{array}$ \\
\hline CB5I5945 & -0.36 & -0.49 & [NR] [NP_683732] RNA binding motif protein 5 [Mus musculus] \\
\hline CA057448 & -0.30 & -0.33 & UNKNOWN \\
\hline CA036745 & -0.62 & -0.74 & $\begin{array}{l}\text { [NT] [XM_53250I] PREDICTED: Canis familiaris similar to Chimerin (chimaerin) } 2 \\
\text { (LOC475267), mRNA }\end{array}$ \\
\hline CB509472 & -0.29 & -0.42 & UNKNOWN \\
\hline CB494192 & 0.23 & 0.33 & [GO] [P094II] Phosphoglycerate kinase I (EC 2,7,2,3), \\
\hline CB496589 & -0.49 & -0.82 & UNKNOWN \\
\hline CB5I3882 & -0.48 & -0.60 & $\begin{array}{l}\text { [NR] [XP_4I3822] PREDICTED: similar to normal mucosa of esophagus specific I } \\
\text { [Gallus gallus] }\end{array}$ \\
\hline CK990857 & -0.64 & -1.11 & UNKNOWN \\
\hline
\end{tabular}

cDNAs or sets of cDNA putatively sensitive to estrogen exposure as judged by the presence on the top 250-lists ranked by moderated t-statistics on both 0.87 and $10 \mathrm{ng}$ EE2/L exposure experiments in male juvenile rainbow trout. cDNAs corresponding to genes that were selected for qPCR analysis are marked with bold text. Note that several cDNAs may likely correspond to the same gene. 

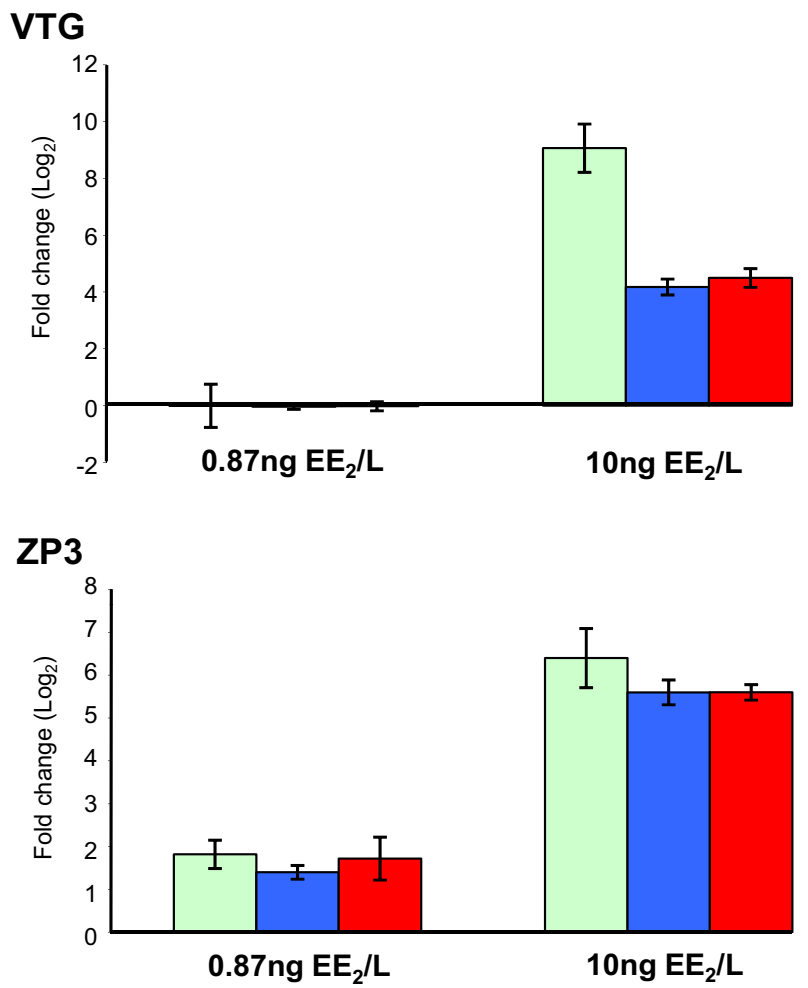

\section{nm23}

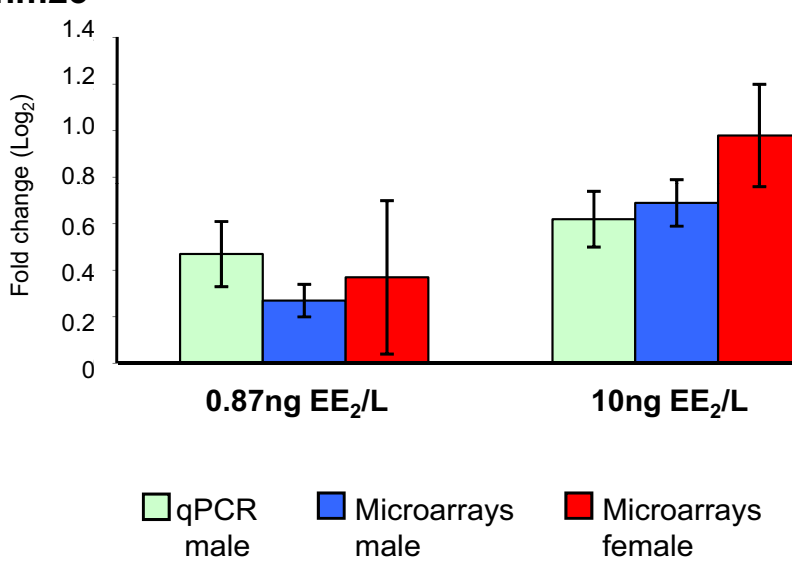

Figure I

Gene expression changes of VTG, ZP3 and nm23 measured by $\mathbf{q P C R}$ and microarray. Hepatic gene expression in rainbow trout of vitellogenin (VTG), zona pellucida protein 3 (ZP3) and a nucleoside diphosphate kinase $(\mathrm{nm} 23)$ after $\mathrm{EE}_{2}$ exposure measured with QPCR (green bars, male fish) or microarray (blue bars, male fish: red bars, female fish). Values are expressed as fold change $\left(\log _{2}\right)$ compared to control fish. Paired student's ttests (single sided) were performed on the QPCR data to confirm/ test the putative regulation suggested from microarray data. VTG, $\mathrm{ZP} 3$ and nm23 were confirmed to be significantly up-regulated in fish exposed to $10 \mathrm{ng} / \mathrm{L}(\mathrm{p}=0.00 \mathrm{I}, 0.00 \mathrm{I}$ and 0.007 respectively, four biological replicates in each group). ZP3 and $\mathrm{nm} 23$, but not VTG were up-regulated in fish exposed to $0.87 \mathrm{ng} / \mathrm{L}(\mathrm{p}=0.0004$, 0.006 and 0.5 respectively, eight biological replicates in each group) in accordance with the microarray data. they were identical to fabp3 and nm23 [EMBL:U95296, AF350241] in rainbow trout (data not shown).

\section{Discussion}

Our meta-analysis correctly identified some of the most well known estrogen-responsive genes (VTG, ZP3, ZP2). This suggests that the approach has a good potential to identify other robust, less well known estrogen-regulated genes. We also showed that ZP3 and a hepatic nucleoside diphosphate kinase nm 23 are more sensitive to estrogenic exposure than the widely used biomarker VTG. As far as we know, no other microarray study has identified the effects of as low concentrations of estrogen as used here. The recognition of nm23 induction as a highly sensitive response is therefore a novel finding. Thus we propose that analyses of nm23 together with ZP genes may increase the possibilities to detect an exposure to low levels of estrogenic compounds in fish. However, more studies are required in order to fully assess the potential of nm23 as a biomarker.

Sensitive biomarkers can be used as early warning signals to indicate exposure and thus potential risk of adverse effects. It has been suggested that the induction of ZP mRNAs are more sensitive than induction of VTG $[9,23]$. However expression of ZP genes can, as most genes, be affected by other environmental factors, for example cortisol exposure [10-12]. The regulation of a single gene is rarely sufficient to conclusively demonstrate a specific exposure, but a combination of responses would together potentially increase the degree of evidence.

We identified nine genes (or groups of paralog genes) that were affected by estrogen in at least three out of the four studies included in the meta-analysis. The known estrogen-responsive genes VTG and ZP3 were up-regulated in all four studies. The robust gene expression changes of $\mathrm{ZP} 3, \mathrm{~nm} 23$ and fabp3 were also tentatively identified to be sensitive. However, the induction of fabp3 was not confirmed by qPCR. The incorrect identification from microarray data might be explained by cross hybridization to related mRNAs, a known problem for cDNA microarrays. Nm23, on the other hand, was confirmed with QPCR to be significantly induced both by a low and a high water concentration of $\mathrm{EE}_{2}$. In addition, microarray results from the other studies of rainbow trout exposed to $50 \mathrm{ng} \mathrm{EE_{2 }} / \mathrm{L}$ and dietary exposed to $5 \mu \mathrm{g} / \mathrm{g}$ of $\mathrm{E}_{2}$ further supports an estrogen-induction of nm23 in rainbow trout during different exposure conditions $[20,22]$. The study of estrogen-exposed medaka did not report nm23 as an estrogen-responsive gene but it is unclear if nm 23 was represented on the medaka microarray [16]. Whether nm23 is regulated by estrogen in other fish species is still an open question, although mammalian studies suggest a conserved induction mechanism [24]. 
Table 2: A summary of the four different studies used in the meta-analysis

\begin{tabular}{|c|c|c|c|c|}
\hline & Present study & Hook et al. 2006 & Tilton et al. 2006 & Kishi et al. 2006 \\
\hline Species & O.mykiss & O.mykiss & O.mykiss & O.latipes \\
\hline Sex & juvenile & male & juvenile & male \\
\hline $\begin{array}{l}\text { Estrogenic } \\
\text { substance }\end{array}$ & $\mathrm{EE}_{2}$ & $\mathrm{EE}_{2}$ & $E_{2}$ & $\mathrm{E}_{2}$ \\
\hline Exposure & Water, $10 \mathrm{ng} / \mathrm{L}$ & Water, $50 \mathrm{ng} / \mathrm{L}$ & Dietary, 5 ppm & Water, $100 \mathrm{ng} / \mathrm{L}$ \\
\hline $\begin{array}{l}\text { Water } \\
\text { temperature }\left(C^{\circ}\right)\end{array}$ & 10 & 12 & 12 & 24 \\
\hline Duration (days) & 14 & 7 & 12 & 21 \\
\hline Platform & $\begin{array}{c}\text { Two-channel spotted cDNA } \\
\text { (GRASP } 16 \mathrm{k} \text { v.l) }\end{array}$ & $\begin{array}{c}\text { Two-channel spotted cDNA } \\
\text { (GRASP } 16 \text { k v.l) }\end{array}$ & $\begin{array}{l}\text { Two-channel spotted } \\
\text { cDNA (GRASP } 3.7 \mathrm{k} \mathrm{v.l)}\end{array}$ & $\begin{array}{l}\text { One-channel oligonucleotide } \\
\text { (60 mer) (Kishi et al. 2006) }\end{array}$ \\
\hline $\begin{array}{l}\text { Experimental } \\
\text { Setup }\end{array}$ & $\begin{array}{l}\text { Direct comparison, } 8 \\
\text { biological replicates }\end{array}$ & $\begin{array}{c}\text { Direct comparison, } 3 \\
\text { biological } \times 3 \text { technical } \\
\text { replicates }\end{array}$ & $\begin{array}{c}\text { Reference design, } 2 \\
\text { biological } \times 2 \text { technical } \\
\text { replicates }\end{array}$ & $\begin{array}{l}6 \text { control and } 3 \text { exposed } \\
\text { biological replicates }\end{array}$ \\
\hline $\begin{array}{l}\text { Number of cDNAs/ } \\
\text { probes }\end{array}$ & 16006 & 16006 & 3700 & 22587 \\
\hline Pre-processing & $\begin{array}{l}\text { Loess, no background } \\
\text { correction }\end{array}$ & Loess & Loess & Robust Multichip \\
\hline $\begin{array}{l}\text { Statistical method } \\
\text { used for ranking }\end{array}$ & Moderated t-statistic & Student t-statistic & fold change & Student t-statistic \\
\hline $\begin{array}{l}\text { Selected cDNA/ } \\
\text { probes }\end{array}$ & $\begin{array}{l}250 \text { (167 induced, } 83 \\
\text { suppressed) }\end{array}$ & $\begin{array}{l}\text { I89 (48 induced, |4I } \\
\text { suppressed) }\end{array}$ & $\begin{array}{c}366 \text { (127 induced, } 239 \\
\text { suppressed) }\end{array}$ & $\begin{array}{l}381 \text { (242 induced, } 139 \\
\text { suppressed) }\end{array}$ \\
\hline $\begin{array}{l}\text { Source for } \\
\text { sequences }\end{array}$ & cDNA, cGRASP & cDNA, cGRASP & cDNA, cGRASP & $\begin{array}{c}\text { Transcripts, TIGR (OLGI } \\
\text { release } 4.0)\end{array}$ \\
\hline $\begin{array}{l}\text { Number of } \\
\text { matches }\left(a_{\text {in }} \text { D.rerio }\right.\end{array}$ & 91 & 89 & 190 & 184 \\
\hline
\end{tabular}

a) A match is defined as a tblastx hit with a E-value less than 10-25.

$\mathrm{Nm} 23$ belongs to a larger class of nucleoside disphophate kinases that exist in multiple isoforms and are highly conserved throughout evolution. The investigated nm23 have been sequenced in rainbow trout [EMBL AF350241], Atlantic salmon [EMBL AF045187] and zebrafish [EMBL AF201764]. The salmon and zebrafish nm23 shows high similarity to the human nm23-H1 and $\mathrm{H} 2$ genes. A phyl-

\begin{tabular}{|c|c|c|c|c|c|}
\hline $\begin{array}{l}\text { Ensembl } \\
\text { Transcript }\end{array}$ & Annotation & $\begin{array}{l}\text { Present } \\
\text { Study }\end{array}$ & $\begin{array}{l}\text { Hook et } \\
\text { al. } 2006\end{array}$ & $\begin{array}{l}\text { Tilton et } \\
\text { al. } 2006\end{array}$ & $\begin{array}{l}\text { Kishi et } \\
\text { al. } 2006\end{array}$ \\
\hline 61165 & vitellogenin 2 & & & & \\
\hline $\begin{array}{l}61744 / 61751 / \\
65820\end{array}$ & zona pellucida glycoprotein 3 & & & & \\
\hline 49240 & transducer of ERBB2, 1a & & & & \\
\hline $\begin{array}{l}56088 / 77745 / \\
8439 / 24598\end{array}$ & zona pellucida glycoprotein 2 & & & & \\
\hline $26180 / 33724$ & $\begin{array}{l}\text { fatty acid binding protein } \mathbf{3} \text { (fabp3) or } \\
\text { fatty acid binding protein } 7, \text { brain, a }\end{array}$ & & & & \\
\hline $55579 / 74814$ & peptidylprolyl isomerase B & & & & \\
\hline $59139 / 64339$ & $\begin{array}{l}\text { non-metastatic cells 2, protein } \\
\text { (NM23B) }\end{array}$ & & & & \\
\hline 56095 & fatty acid binding protein 10 , liver basic & & & & \\
\hline 2842 & cytochrome P450 & & & & \\
\hline
\end{tabular}

\section{Figure 2}

Robust estrogen-responsive genes. Genes affected by estrogen in at least three out of four studies used in the meta-analysis. Red refers to an up-regulation, whereas green refers to a down-regulation. Only the zebrafish transcripts with the best TBLASTX hit to each of the probes from the different studies are presented in the figure. Genes that were selected for qPCR analysis are marked with bold text. ogenetic analysis suggests that $\mathrm{nm} 23-\mathrm{H} 1$ and $\mathrm{H} 2$ have arisen by gene duplication after the speciation event that gave rise to modern teleost fish and tetrapods [25]. Therefore it is assumed that the salmonid genome would only have one gene homologue to the $\mathrm{nm} 23-\mathrm{H} 1$ and $-\mathrm{H} 2$ genes. In mammals the $\mathrm{nm} 23-\mathrm{H} 2$ gene encodes the cMYC transcription factor and the $\mathrm{nm} 23-\mathrm{H} 1$ gene has been shown to be metastasis associated [24]. Moreover, the $\mathrm{nm} 23-\mathrm{H} 1$ gene and protein is up-regulated by $\mathrm{E}_{2}$-treatment in human breast carcinoma cell lines. This induction seems to be mediated, at least in part, at the transcriptional level via the estrogen receptor $\alpha$ binding to an estrogen responsive element in the promoter region of the human nm23-H1 [24]. The physiological function of $\mathrm{nm} 23$ in fish remains to be determined as well as the possibilities of a regulation by other factors than estrogen (specificity) and the robustness of the response during more complex exposure scenarios.

To be useful as a biomarker, a response should ideally be as robust as possible. In the meta-analysis we tested gene responses for robustness between species, exposure conditions and analytical platforms. Combining microarray data from different species and platforms is a challenging task, particularly when sequence information and good annotations are limited. We have addressed the cross platform/cross species comparison by using the zebrafish transcriptome as a reference. In contrast to most other fish 
species zebrafish has the advantage of being both well sequenced and well annotated. However, using zebrafish as a reference also has limitations, e.g. a lack of identified homologes for some genes. The results in the meta-analysis were also influenced by the shortage of available microarray raw data and therefore we had to accept the different statistical approaches used for selecting estrogenresponsive genes in the different studies.

It is certainly possible that more than nine hepatic genes are robustly regulated by estrogen in the analyzed species/ conditions. We have only included comprehensive fish arrays in the meta-analysis. Nevertheless, many genes are still likely to be represented on only one or a few of the array platforms which limits the possibility of identifying robust responses. The choice of microarray platform also affects the possibilities to accurately identify differentially expressed genes. Amplicon arrays (cDNA arrays) show less concordance with other platforms, for example qPCR and commercially produced high density arrays with oligonucleotide probes or cDNA arrays with synthetic oligonucleotides [26]. Although, it has been shown that when two independent platforms give consistent results, the outcome of qPCR analysis will most often also be in agreement $[27,28]$. This adds confidence that several of the differentially expressed genes identified by the meta-analysis indeed are relatively robust responses.

By making the data on putative sensitive and/or robust gene responses public, it can be used as a base for further investigations on the effects of environmental estrogens in fish in order to develop biomarkers or to increase the understanding of the physiological impact of environmental estrogens.

\section{Conclusion}

We have used microarrays to identify a range of potentially sensitive and/or robust gene expression changes in fish exposed to estrogen. We have identified the induction of ZP3 and a hepatic nm23 mRNA as being both sensitive and presumably robust responses. After further evaluation, nm23 induction would therefore be a good candidate biomarker together with ZP genes to reveal exposure to low levels of estrogens not sufficient to induce VTG but still with potential to affect gonadal differentiation of fish.

\section{Methods}

Experimental animals, exposure and preparation of hepatic total RNA

Fish from a previously published study were analysed [29]. The experimental setup was in short: 15, 14 and 14 juvenile rainbow trout (weighing around $100 \mathrm{~g}$ ) were divided into three aquaria and exposed for two weeks to measured concentrations of $0,0.87$ and $10 \mathrm{ng} / \mathrm{L}$ respectively of $\mathrm{EE}_{2}$ in a flow-through system. Water samples were taken from the low and high $\mathrm{EE}_{2}$ concentration aquaria, before the transfer of the fish, on day 8 and on day 13 . One sample was collected from the control aquaria on day 8. Solid phase columns were used to extract and purify $\mathrm{EE}_{2}$ from the water followed by derivatization (pentafluorobenzoylester) and further purification. $\mathrm{EE}_{2}$-concentrations were determined using GC/MS. The limit of detection (signal-to-noise set to 5) was $0.01 \mathrm{ng} / \mathrm{L}$. Samuelsson et al showed that the fish exposed to $10 \mathrm{ng} / \mathrm{L} \mathrm{EE}_{2}$ had significantly increased plasma levels of VTG, increased hepatosomatic index and the plasma metabolite profile were affected by the treatment. However, in the fish exposed to $0.87 \mathrm{ng} / \mathrm{L}$ neither induction of plasma VTG protein nor an altered metabolite pattern could be demonstrated using a specific VTG-ELISA and NMR respectively [29]. Gene responses in liver are widely used as biomarkers for environmental pollutants, i.e. estrogens, and the hepatic responses to estrogens are not restricted to a short developmental period. A prerequisite for our meta-analysis was availability of additional arraydata from the same tissue in estrogen-exposed fish. Only hepatic microarray data was available in the literature, which therefore also contributed to our choice of tissue. Livers were collected and snap frozen in liquid nitrogen. Total hepatic RNA was isolated from individual trout liver using TRI reagent (Sigma chemicals Co, St Louis, MO, USA). RNA quality and quantity were assessed by agarose gel electrophoresis and spectrophotometric measurements (Nanodrop 1000, NanoDrop Technologies, USA and Spectra MAXplus, Molecular Devices, CA, USA).

\section{Microarray chip, hybridisation and wash}

Salmonid cDNA microarrays (GRASP16k v1) were purchased from cGRASP, Univerity of Victoria, BC, Canada [21]. Microarray fabrication and quality control have previously been described in von Schalburg et al. [30]. The array contains 13,421 Atlantic salmon (Salmon salar) cDNAs and 2,576 rainbow trout cDNAs that together with a few more expressed sequence tags (ESTs) from other salmonid fish results in 16006 spotted cDNAs in total. It has previously been shown that the sequence similarity between the Atlantic salmon and rainbow trout is sufficiently high for cross species use of the array [31].

Several cDNAs on the array correspond to the same gene and to reduce redundancy, a sequence based clustering was made as follows. Each cDNA sequence was compared to all other sequences on the array using BLAST [32]. A stringent cut-off value of at least $98 \%$ sequence similarity over 250 base-pairs or more was used to define equality. Single-link clustering was then applied which resulted in 13853 sets of cDNAs.

Slide preparation have been described in detail in von Schalburg et al. [30]. Briefly, $8 \mu \mathrm{g}$ of total RNA was reverse 
transcribed and labelled using SuperScript Indirect cDNA labelling System kit (Invitrogen, Carlsbad, CA, USA) and fluorescent dyes $\mathrm{Cy} 5$ and $\mathrm{Cy} 3$ (GE Healthcare, Buckinghamshire, UK). cDNA from one control fish and one exposed fish were labelled and hybridised to the same array. Every other pair was dye swapped to compensate for cyanine flour effects. Eight male control fish were paired with male fish exposed to $0.87 \mathrm{ng}$ EE2/L matching individual weights and lengths as closely as possible. Four of the same male control fish were also paired to fish exposed to $10 \mathrm{ng}$ EE2/L. In the same way, four female control fish were paired both to females exposed to the low dose and the high dose. Hybridisation and wash were performed as described before by von Schalburg et al. [30] with the exception of the prehybridization that was preformed for $1.5 \mathrm{~h}$ in $5 \mathrm{xSSC}, 0.1 \% \mathrm{SDS}, 0.2 \% \mathrm{BSA}$ at $49^{\circ} \mathrm{C}$. In total 20 microarrays were analysed.

\section{Microarray analyses}

Fluorescent images of hybridized arrays were acquired using an Agilent MicroArray Scanner (Agilent Technologies, Palo Alto, CA, USA). Intensity data were extracted from TIFF images using Imagene version 6.0 (BioDiscovery, CA, USA). The statistical analysis was performed using the R package [33] LIMMA [34], which is available at the Bioconductor repository $[35,36]$. For each cDNA on the chip, $\mathrm{M}$-values ( $\log _{2}$ fold change) and A-values (average $\log _{2}$ intensity) were calculated. Loess normalization was applied to each array to remove intensity dependent trends [37]. For each set of cDNAs (defined above), an Mvalue was calculated by taking the average of the $M$-values of all the cDNAs in the set. Next, each set was annotated based on the cDNA with highest A-value (i.e. the spot with best hybridization). Finally, the sets of cDNAs were ranked by moderated t-statistic [34] to reduce the proportion of false positives. Data from the complete microarray experiment is available according to the MIAME guidelines at Array Express [38].

\section{Meta-analysis}

Microarray data from four different studies on estrogenexposed fish were subjected to a meta-analysis with the aim to identify robust estrogen responsive genes $[16,20,22]$. Another study with estrogen-exposed adult female zebrafish was excluded since the control fish presumable had high levels of endogenuous estrogen (neither VTG nor ZP3 was regulated in this study) [39]. To our knowledge, no other relevant microarray studies covering more than $3000 \mathrm{cDNAs} /$ transcripts were publicly available (i.e. open access to transcript sequences) in October 2006 when we performed the meta-analyses. The studies included are summarized in Table 2.

The meta-analysis was done as follows. For each study, a list of the reported estrogen-regulated genes and the corre- sponding transcripts/cDNA-sequences was created. Note that the studies used different statistical methods to find the regulated genes (Table 2).

From the present study, the topmost 250 sets of cDNA from fish (both female and male) exposed to 10 ng EE2/L were chosen. To compare the platforms, zebrafish was used as a reference species. It was chosen since it is almost fully sequenced and well annotated compared to the other species involved. All transcripts/cDNAs were compared to the zebrafish transcriptome available through Ensembl release 40 (26,679 in total) using tblastx [32]. A cut-off E-value of $10^{-25}$ was used to define a match. This resulted in a list of 360 zebrafish transcripts that had a match to transcripts/cDNAs from at least two studies (the transcripts should be regulated in the same direction). The list of zebrafish transcripts contained both multiple transcripts from the same gene (different splice variants) and paralogs and therefore the list was clustered into groups of transcripts. A similarity indicator matrix was created by comparing all transcripts in the list to each other using tblastx. Pairs of transcripts with an E-value of $10^{-50}$ or less were defined to be equal. Otherwise the distance was set to zero. Single link clustering was then applied to create the groups of transcripts. Finally, all transcripts were annotated using Ensembl. The complete list of transcripts is available in Additional file 1.

\section{Quantitative RT-PCR}

To confirm regulation of four selected genes, the abundances of the mRNAs were analysed with qPCR. The qPCR was performed on isolated total RNA from the same fish used in the microarray analysis. Total RNA $(0.5 \mu \mathrm{g})$ was reverse transcribed in duplicate with a mixture of random hexamers and oligo(dT) primers, using the iScript ${ }^{\mathrm{TM}} \mathrm{cDNA}$ Synthesis Kit (Bio-Rad, Hercules, CA, USA). The cDNA synthesis was performed according to the manufacturer's instructions, except for a scale-down of the reaction volume to $10 \mu \mathrm{l}$. Pooled RNA samples were used as no reverse transcriptase controls to control for genomic contamination. It was discovered that three samples might have been contaminated with DNA. These samples were treated with DNase and new qPCR analyses were done. PCR primers for ZP3 [EMBL:AF231708], nm23 [EMBL:AF350241], fabp3 [EMBL:U95296], VTG [EMBL:X92804], $\beta$-actin [EMBL:AJ438158] and ubiquitin [EMBL:AB036060] were designed using Primer3 software [40]. Primer sequences were as follows: 5 '-ccctgcgtatctttgtgga-3' and 5'-gtgggaacctgtcattttgg-3' for ZP3; 5'-ccttcttccctggtctcgt-3' and 5'-gatgatgttcetgeccactt-3' for $\mathrm{nm} 23$; 5'ctttccctgtttccectcct-3' and $5^{\prime}$-tgctgtgtgcttcttgctactc- $3^{\prime}$ for VTG; 5'-ggggcagtatggcttgtatg-3' and 5'-ctggcaccctaatcacctct-3' for beta actin; 5'-cgatagacggtggtaagatgg-3' and 5'aggtgtggcaaagggtagtg-3' for fabp3 ; 5'- atgtcaaggccaagatccag $-3^{\prime}$ and $5^{\prime}$-ataatgectccacgaagacg $-3^{\prime}$ for ubiquitin. For 
all genes except the reference gene, ubiquitin (for which the qPCR was performed according to a previously published protocol [41]), the qPCR reactions contained $1 \times$ Real Time PCR Buffer, $3 \mathrm{mM} \mathrm{MgCl}{ }_{2}, 400 \mu \mathrm{M}$ dNTP, 300 nM of each primer, 1 U TaKaRa Ex Taq ${ }^{\mathrm{TM}} \mathrm{R}$-PCR Version 2.1 (TaKaRa Bio Inc., Shiga, Japan), 0.25× SYBR Green I (Molecular Probes Eugene, OR, USA) and cDNA corresponding to 20 ng total RNA, in a final reaction volume of $20 \mu \mathrm{l}$. Real-time qPCR was performed on a Stratagene $\mathrm{Mx} 3005 \mathrm{p}$ with $30 \mathrm{sec}$ initial denaturation at $95^{\circ} \mathrm{C}$, followed by 45 cycles of $95^{\circ} \mathrm{C}$ for 20 s, $60^{\circ} \mathrm{C}$ for 20 s and $72^{\circ} \mathrm{C}$ for 20 s. A melting curve analysis was performed after each run to verify specific amplification. In addition the qPCR products were subjected to an agarose gel electrophoresis to confirm the expected size of the product. Both beta actin and ubiquitin were chosen as potential reference genes. Beta actin had a high variance and also a tendency to be regulated in the high dose group and therefore only ubiquitin was used. All signals were normalized against ubiquitin and ratios were calculated for exposed fish compared to control fish paired in the same manner as in the microarray analysis. Paired single-sided student's t-test were performed to test for significantly regulated genes. Since all samples could not be run at the same occasion, two standard samples were run at all occasions in order to enable a compensation for a possible run to run variation. Applying a run to run factor made little difference and the differently expressed genes VTG, ZP3 and $\mathrm{nm} 23$ were significant up-regulated both with and without applying the factor. The presented GPCR results are calculated without this factor.

\section{Authors' contributions}

LG participated in the planning of the study, the sampling of the fish, carried out the molecular biology, participated in the statistical analysis, in the meta-analysis and drafted the manuscript. EK performed the statistical analysis and the meta-analysis and participated in the drafting of the manuscript. LF participated in the planning of the study. ON supervised the statistical analysis. DGJL planned the study, participated in the sampling, supervised and drafted the manuscript. All authors read and approved the final manuscript.

\section{Additional material}

\section{Additional File 1}

Transcripts or groups transcripts identified as differentially expressed in at least two of the four different studies

Click here for file

[http://www.biomedcentral.com/content/supplementary/14712164-8-149-S1.xls]

\section{Acknowledgements}

The authors wish to thank cGRASP (B. F. Koop and W. Davidson) for providing the cDNA microarrays and G. Cooper for technical assistance/ advice. We also want to thank $L$. Samuelsson for performing the fish exposure experiment. In addition we would like to thank the Lundberg Laboratories for Cancer Research at the Sahlgrenska Academy at Göteborg University for letting us use their Agilent scanner and TATAA Biocenter, Göteborg, Sweden for performing the GPCR analysis. This research was supported by the Swedish Research Council for Environment, Agricultural Sciences and Spatial Planning (FORMAS) (DGJL, LF), the Foundation for Strategic Environmental Research (MISTRA) (DGJL, LF), the Swedish Research Council (VR) (DGJL), Renova AB (LG), The Swedish Research School for Genomics and Bioinformatics (ON) and the Adlerbertska Research Foundation (LG, DGJL).

\section{References}

I. Desbrow C, Rutledge EJ, Brighty GC, Sumpter JP, Waldock M: Identification of estrogenic chemicals in STW effluent: I. Chemical fractionation and in vitro biological screening. Environ $\mathrm{Sci}$ Technol 1998, 32(II): 1549-1558.

2. Larsson DGJ, Adolfsson-Erici M, Parkkonen J, Pettersson M, Berg AH, Olsson PE, Förlin L: Ethinyloestradiol - an undesired fish contraceptive? Aquat Toxicol 1999, 45:9I-97.

3. Purdom CE, Hardiman PA, Bye VJ, Eno NC, Tyler CR, Sumpter JP: Estrogenic effects of effluents from sewage treatment works. Chem Ecol 1994, 8:275-285.

4. Jobling S, Coey S, Whitmore JG, Kime DE, Van Look KJ, McAllister BG, Beresford N, Henshaw AC, Brighty G, Tyler CR, Sumpter JP: Wild intersex roach (Rutilus rutilus) have reduced fertility. Biol Reprod 2002, 67(2):515-524.

5. Routledge EJ, Sheahan D, Desbrow C, Brighty GC, Waldock M, Sumpter JP: Identification of estrogenic chemicals in STW effluent. 2. In vivo responses in trout and roach. Environ $\mathrm{Sci}$ Technol 1998, 32(I I): 1559-1565.

6. Sumpter JP, Jobling S: Vitellogenesis as a biomarker for contamination of the aquatic environment. Environ Health Perspect 1995, 103(Suppl. 7): 173-178.

7. Örn S, Holbech H, Madsen HT, Norrgren L, Petersen IG: Gonad development and vitellogenin production in zebrafish (Danio reio) exposed to ethinylestradiol and methyltestosterone. Aquat Toxicol 2003, 65:397-4II.

8. Parrott JL, Blunt BR: Life-cycle exposure of fathead minnows (Pimephales promelas) to an ethinylestradiol concentration below I $\mathrm{ng} / \mathrm{L}$ reduces egg fertilization success and demasculinizes males. Environ Toxicol 2005, 20(2): |3I-I4I.

9. Thomas-Jones E, Thorpe K, Harrison N, Thomas G, Morris C, Hutchinson T, Woodhead S, Tyler C: Dynamics of estrogen biomarker responses in rainbow trout exposed to I7beta-estradiol and I7alpha-ethinylestradiol. Environ Toxicol Chem 2003, 22(12):300I-3008.

10. Berg AH, Westerlund L, Olsson PE: Regulation of Arctic char (Salvelinus alpinus) egg shell proteins and vitellogenin during reproduction and in response to 17 beta-estradiol and cortisol. Gen Comp Endocrinol 2004, I35(3):276-285.

II. Larsson DGJ, Mayer I, Hyllner SJ, Forlin L: Seasonal variations of vitelline envelope proteins, vitellogenin, and sex steroids in male and female eelpout (Zoarces viviparus). Gen Comp Endocrinol 2002, 125(2): 184-196.

12. Rotchell JM, Ostrander GK: Molecular markers of endocrine disruption in aquatic organisms. J Toxicol Environ Health $B$ Crit Rev 2003, 6(5):453-496.

13. Snape JR, Maund SJ, Pickford DB, Hutchinson TH: Ecotoxicogenomics: the challenge of integrating genomics into aquatic and terrestrial ecotoxicology. Aquat Toxicol 2004, 67(2): 143-154.

14. Miracle AL, Ankley GT: Ecotoxicogenomics: linkages between exposure and effects in assessing risks of aquatic contaminants to fish. Reprod Toxicol 2005, I9(3):32I-326.

15. Ju Z, Wells MC, Walter RB: DNA microarray technology in toxicogenomics of aquatic models: Methods and applications. Comp Biochem Physiol C Toxicol Pharmacol 2006. 
16. Kishi K, Kitagawa E, Onikura N, Nakamura A, Iwahashi H: Expression analysis of sex-specific and I 7 beta-estradiol-responsive genes in the Japanese medaka, Oryzias latipes, using oligonucleotide microarrays. Genomics 2006, 88(2):24I-25I

17. Lettieri T: Recent applications of DNA microarray technology to toxicology and ecotoxicology. Environ Health Perspect 2006 I | 4( I):4-9.

18. Moens LN, van der Ven K, Van Remortel P, Del-Favero J, De Coen WM: Expression profiling of endocrine disrupting compounds using a customized cyprinus carpio cDNA microarray. Toxicol Sci 2006.

19. van der Ven K, Keil D, Moens LN, Hummelen PV, van Remortel P, Maras M, De Coen W: Effects of the antidepressant mianserin in zebrafish: Molecular markers of endocrine disruption. Chemosphere 2006.

20. Hook SE, Skillman AD, Small JA, Schultz IR: Gene expression patterns in rainbow trout, Oncorhynchus mykiss, exposed to a suite of model toxicants. Aquat Toxicol 2006, 77(4):372-385

21. consortium Genomics Research on All Salmon [http:// web.uvic.ca/cbr/grasp]

22. Tilton SC, Givan SA, Pereira CB, Bailey GS, Williams DE: Toxicogenomic profiling of the hepatic tumor promoters indole-3. carbinol, I 7 beta-estradiol and beta-naphthoflavone in rainbow trout. Toxicol Sci 2006, 90(I):6I-72.

23. Celius T, Matthews JB, Giesy JP, Zacharewski TR: Quantification of rainbow trout (Oncorhynchus mykiss) zona radiata and vitellogenin mRNA levels using real-time PCR after in vivo treatment with estradiol- 17 beta or alpha-zearalenol. I Steroid Biochem Mol Biol 2000, 75(2-3): I09-II9.

24. Lin $\mathrm{KH}$, Wang WJ, Wu YH, Cheng SY: Activation of antimetastatic Nm23-HI gene expression by estrogen and its alphareceptor. Endocrinol 2002, I 43(2):467-475.

25. Murphy M, Harte T, Mclnerney J, Smith TJ: Molecular cloning of an Atlantic salmon nucleoside diphosphate kinase cDNA and its pattern of expression during embryogenesis. Gene 2000, 257(I): | 39-|48.

26. Woo Y, Affourtit J, Daigle S, Viale A, Johnson K, Naggert J, Churchill G: A comparison of CDNA, oligonucleotide, and Affymetrix GeneChip gene expression microarray platforms. J Biomol Tech 2004, I 5(4):276-284.

27. Larkin JE, Frank BC, Gavras H, Sultana R, Quackenbush J: Independence and reproducibility across microarray platforms. Nat Methods 2005, 2(5):337-344.

28. Severgnini M, Bicciato S, Mangano E, Scarlatti F, Mezzelani A, Mattioli M, Ghidoni R, Peano C, Bonnal R, Viti F, Milanesi L, De Bellis G, Battaglia $C$ : Strategies for comparing gene expression profiles from different microarray platforms: application to a casecontrol experiment. Anal Biochem 2006, 353(I):43-56.

29. Samuelsson LM, Forlin L, Karlsson G, Adolfsson-Erici M, Larsson DG]: Using NMR metabolomics to identify responses of an environmental estrogen in blood plasma of fish. Aquat Toxicol 2006, 78(4):34l-349.

30. von Schalburg KR, Rise ML, Cooper GA, Brown GD, Gibbs AR, Nelson CC, Davidson WS, Koop BF: Fish and chips: various methodologies demonstrate utility of a 16,006-gene salmonid microarray. BMC Genomics 2005, 6:126.

31. Rise ML, von Schalburg KR, Brown GD, Mawer MA, Devlin RH, Kuipers N, Busby M, Beetz-Sargent M, Alberto R, Gibbs AR, Hunt P Shukin R, Zeznik JA, Nelson C, Jones SR, Smailus DE, Jones SJ, Schein JE, Marra MA, Butterfield YS, Stott JM, Ng SH, Davidson WS, Koop BF: Development and application of a salmonid EST database and CDNA microarray: data mining and interspecific hybridization characteristics. Genome Res 2004, I 4(3):478-490.

32. Altschul SF, Madden TL, Schaffer AA, Zhang J, Zhang Z, Miller W, Lipman DJ: Gapped BLAST and PSI-BLAST: a new generation of protein database search programs. Nucleic Acids Res 1997, 25(I 7):3389-3402.

33. R Development Core Team: R: A Language and Environment for Statistical Computing. 2006 [http://www.R-project.org]. R Foundation for Statistical Computing

34. Smyth GK: Linear models and empirical bayes methods for assessing differential expression in microarray experiments. Stat Appl Genet Mol Biol 2004, 3(I):Article3.

35. Gentleman RC, Carey VJ, Bates DM, Bolstad B, Dettling M, Dudoit S, Ellis B, Gautier L, Ge Y, Gentry J, Hornik K, Hothorn T, Huber W, lacus S, Irizarry R, Leisch F, Li C, Maechler M, Rossini AJ, Sawitzki G,
Smith C, Smyth G, Tierney L, Yang JY, Zhang J: Bioconductor: open software development for computational biology and bioinformatics. Genome Biol 2004, 5( I 0):R80.

36. Bioconductor open source software for bioinformatics [http://www.bioconductor.org/]

37. Yang YH, Dudoit S, Luu P, Lin DM, Peng V, Ngai J, Speed TP: Normalization for cDNA microarray data: a robust composite method addressing single and multiple slide systematic variation. Nucleic Acids Res 2002, 30(4):el5.

38. Brazma A, Parkinson H, Sarkans U, Shojatalab M, Vilo J, Abeygunawardena N, Holloway E, Kapushesky M, Kemmeren P, Lara GG, Oezcimen A, Rocca-Serra P, Sansone SA: ArrayExpress--a public repository for microarray gene expression data at the $\mathrm{EBI}$. Nucleic Acids Res 2003, 3 I (I):68-7I.

39. Hoffmann JL, Torontali SP, Thomason RG, Lee DM, Brill JL, Price BB Carr GJ, Versteeg DJ: Hepatic gene expression profiling using genechips in zebrafish exposed to I 7alpha-ethynylestradiol. Aquat Toxicol 2006.

40. Primer3 primer3 www.cgi]

[http://frodo.wi.mit.edu/cgi-bin/primer3/

41. Rise ML, Jones SR, Brown GD, von Schalburg KR, Davidson WS, Koop BF: Microarray analyses identify molecular biomarkers of Atlantic salmon macrophage and hematopoietic kidney response to Piscirickettsia salmonis infection. Physiol Genomics 2004, 20(I):2l-35

Publish with Bio Med Central and every scientist can read your work free of charge

"BioMed Central will be the most significant development for disseminating the results of biomedical research in our lifetime. "

Sir Paul Nurse, Cancer Research UK

Your research papers will be:

- available free of charge to the entire biomedical community

- peer reviewed and published immediately upon acceptance

- cited in PubMed and archived on PubMed Central

- yours - you keep the copyright
BioMedcentral 